\author{
Zavadska D.V. \\ $\mathrm{PhD}$ in Economics, \\ Associate Professor of Banking Department \\ Odessa National Economic University
}

\title{
BANK INNOVATIVE LENDING SYSTEM: TRENDS OF FORMATION AND DIRECTIONS FOR PROMOTING DEVELOPMENT IN UKRAINE
}

The article states that banking system needs to reform, modernize the mechanism of lending, taking into account such an object of lending as innovation, which is a key force for economic growth. It is known that there is no integral methodology for the systematic organization of bank innovative lending, and the works of most scholars are devoted to issues of lending as a system without explaining its essence. The necessity of creating a bank innovative lending system as a set of interrelated subsystems (supporting, managing and managed ones) has been proved. The forms, methods and factors of influence of innovative lending at different levels of the economy have been studied. The input and output parameters of the system have been determined; interrelationship with the external environment - the macro-, meso- and microeconomic level - has been established. The factors of the passive role of bank credit in financing the needs of innovative development of Ukraine have been revealed; and measures for promoting lending innovation activity by the state have been offered.

Key words: bank, innovative lending, system, constituent elements (subsystems), economic levels, factors of influence, state, measures for promoting development.

В статье указано, что банковская система нуждается в реформировании, модернизации механизма кредитования с учетом появления такого объекта кредитования, как инновации, является ключевым двигателем роста экономики. Установлено, что целостная методология системной организации банковского инновационного кредитования отсутствует, а труда большинства ученых посвящены вопросам кредитования как системы без раскрытия ее сущности. Доказана необходимость построения системы банковского инновационного кредитования как совокупности взаимосвязанных между собой подсистем (поддерживающей, управляющей и управляемой). Исследованы формы, методы и фракторы влияния кредитования инновационной деятельности на разных уровнях экономики. Определены параметры входа и выхода системы, установлена взаимосвязь с внешней средой - макро-, мезо- и микроэкономическом уровнях. Раскрыто факторы пассивной роли банковского кредита в финансировании потребностей инновационного развития Украины и предложены меры стимулирования государством процессов кредитования инновационной деятельности.

Ключевые слова: банк, инновационное кредитование, система, составные элементы (подсистемы), экономические уровне, факторы влияния, государство, меры стимулирования развития.

Метою статті є розробка рекомендацій щодо створення та впровадження інноваційної банківської системи в Україні. Інформаційною базою дослідження $є$ результати наукових досягнень у застосуванні системного підходу до вирішення питань фрінансування інноваційних проектів банками, опубліковані в монографрічних дослідженнях та публікаціях у періодичних виданнях. У ході дослідження використовувались наступні загальнонаукові методи та методи: монографічний для вивчення літературних джерел по темах дослідження; формальна логіка - аналіз матеріалів та систематизація підходів до формування банківської інноваційної системи кредитування; наукова абстракція - для теоретичного узагальнення, формулювання висновків; табличне та графрічне представлення результатів досліджень. У статті підкреслюється, що банківська система має реформувати, модернізувати механізм кредитування, враховуючи виникнення такого об'єкта кредитування як інновації, що $є$ ключовою силою економічного зростання. Згідно з результатами аналізу участі банків у кредитуванні економіки визначаються чинники, що сприяють пасивній ролі банківського кредиту в фінансуванні інноваційного економічного розвитку України. Встановлено, що немає єдиної методології систематичної організації банківського інноваційного кредитування, 
а праці більшості вчених присвячені питанням кредитної системи без пояснення її сутності. Сформульовані висновки розкривають мету банківської інноваційної системи кредитування, напрямків підвищення рівня прибутковості та зменшення ризику кредитних та інноваційних банківських операцій. Досліджено форми, методи та фактори впливу кредитування інноваційної діяльності на різних рівнях економіки. Визначено параметри входу та виходу системи, встановлено взаємозв'язок із зовнішнім середовищем - макро-, мезо- та мікроекономічним рівнем. Розкрито чинники пасивної ролі банківського кредиту у фрінансуванні потреб інноваційного розвитку України та запропоновано заходи стимулювання державою процесів кредитування інноваційної діяльності. Практичне значення полягає в тому, що наукові дослідження чітко і послідовно доводять необхідність створення системи банківського інноваційного кредитування та виявляють ії підсистеми, набір яких складається з підтримки (наукової підтримки), управління (оперативного управління) та керованих (кредитних) підсистем.

Ключові слова: банк, інноваційне кредитування, система, складові елементи (підсистеми), економічні рівні, чинники впливу, держава, заходи стимулювання розвитку.

Problem statement. Not all Ukrainian commercial banks are now able to offer customers products that can be implemented by capital-intensive projects, such bank products as investment lending and project financing, directly aimed at financing innovations. The lack of interest from banks is due to the increased level of risk inherent in innovation activity, which is one of the main problems of innovation development in the country.

Today, the issue of reviewing credit and investment policy and developing a new approach in general to the process of lending by commercial banks is relevant, which is in line with the challenges of the economy and current trends. The banking system needs to reform, modernize the lending mechanism, taking into account the emergence of a new lending facility, such as innovation, which is the key force of economic growth.

Insufficient amount of scientific researches on the definition of methodological foundations of interaction of credit and innovations, insignificant part of theoretical research, allowing on the doctrinal level to form the system of financing of investment-innovation require an empirical search for practical solutions. The reduction of profitability of banking operations and high uncertainty of the environment needs to develop new approaches to the relationship of a bank and the entity of innovation, credit portfolio, credit assessment and risk management in financing innovative projects. In this regard, the issues of development of bank innovative lending, as an instrument of financial support for innovative development tasks, are of particular importance.

Analysis of recent research and publications. The study of theoretical and practical aspects of creating a well-organized and well-founded system of financing innovation activity, promoting investment processes, a detailed analysis of the possibilities of capital mobilization for the implementation of innovations by banks takes a leading place in the works of both foreign and domestic scientists.
The leading foreign researchers who study the issues of financing innovations by the banks are: P. Alessandrini, M. Amore, L. Benfratello, S. Chava, J. Cornaggia, P. Hsu, R. Nanda, T. Nicholas and many others.

The theoretical basis for determining the effects of changes in banking sector on the development of innovation and the formation of measures to improve the efficiency of financing innovations has been developed by O. Amosha, B. Heiets, M. Zvieriakov, V. Zymovets, M. Krupka, L. Kuznietsova, I. Lazepko, A. Moroz, O. Obolenskyi, S. Onyshko, A. Peresada, B. Pshyk, S. Tihipko, M. Savluk and other scientists.

In the works of these scholars, the issues of increasing the role of bank investment credit in the general system of financial support for innovation transformations in order to achieve the strategic goal in the development of Ukrainian society also have been considered.

Emphasizing previously unsettled parts of the general problem. Despite a significant amount of scientific research on determining the forms of financial support that innovative enterprises can take advantage of, the problem of financing innovative projects by banks remains unresolved.

A set of issues aimed at the allocation of an independent segment of the financial market the system of bank innovative lending, identification of its elements, providing coordination with tasks at the macro, meso and microeconomic levels, generating synergy effects in the financing of innovation activities in the long run requires further research.

Setting objectives. Among the main factors hindering innovation activity is the high level of transaction costs caused by a faster, compared with inflation, dynamics of prices and tariffs for products and services of natural; a steady increase in real wages at a pace that far exceeds the growth of labor productivity. In the context of the global crisis in Ukraine, macroeconomic indicators have deteriorated significantly, and 
the destruction of the scientific and production potential, which provided a continuous innovation cycle, was particularly dangerous for the country`s economic security.

The insufficient development of these problems of a theoretical and practical nature, the need for scientific research and the search for solutions to the problems of financing reindustrialization and innovative development of the economy through the mechanisms of bank lending led to the choice of the theme and purpose of the study.

The purpose of the study is to develop recommendations for creation and implementation of the bank innovative lending system in Ukraine.

Presentation of the main research material. Bank innovative lending as a source of financial resources for the development of innovative projects has become most widespread in developed countries: in the USA, Israel, Germany, and Japan. $3040 \%$ of all investment goes to the innovation sector through commercial banks [1].

In Ukraine bank credits occupy a small share in credit portfolios, as monetary aspects prevail in Ukraine's current state monetary policy, and there is not enough attention to credit in it. Excess of growth rates of banks ' credit resources over GDP growth rates in Ukraine did not bring the expected positive effects due to separation from real material flows, that is, the credit was isolated from the needs of economic development. This leads to a technological lag of economies in a significant number of regions, but, in the future, if they do not take effective rational decisions on financing innovative development, this will lead to a gradual degradation of the national industrial sphere of the country. The current passive role of bank credit in financing the needs of innovative economic development in Ukraine is determined by the following factors:

- firstly, the lack of adequate long-term and cheap resources in domestic banks, necessary to provide innovative lending to the economy;

- secondly, not quite satisfactory state of legislative and judicial protection of bank-creditors from actions of unscrupulous borrowers;

- thirdly, the current normative base of banking regulation does not fully correspond to the real level of risks of innovative lending; the lack of effective stimulating supervisory mechanisms leads to the creating increased banks ' reserves while lending start-up innovation or venture projects;

- the fourth, a key deterrent factor is the significant level of available overdue loans and noncore assets on the balance sheets of banks, which leads them to the need for higher reserves, and also creates additional costs for the maintenance of mortgaged property.
It is also necessary to note the underdevelopment of institutions of long-term savings in Ukraine (there are no venture, insurance, mutual funds), as well as the stock market (shares and bonds). Banks are practically the only cash holders and their transformation in a certain part because of long-term lending in fixed capital investments [2]. Taking into account the macroeconomic realities that are taking place today in Ukraine, the banking system needs to develop a system of measures for investment support of innovation activities of domestic companies, namely: it is necessary to select projects aimed at developing business of clients, to develop measures to reduce project and credit risks, as well as to form a scheme for financing projects. The banks should help bring innovative projects to the point where their funding can be made, as well as provide a range of services to support these projects. Then, the guarantees of clients' business efficiency will be the basis for management of banks `credit innovative risks.

Implementation of the above mentioned tasks is only possible when using a systematic approach, since a bank innovative lending is under the influence of a large number of external and internal factors and depends on state support of both innovative enterprises and banks themselves. Also, it should be noted that identifying the optimal conditions for the functioning of bank innovative lending needs to determine the scope of the bank's involvement in lending innovative needs for economic growth. Depending on the scope, the innovation and its lending can be carried out on six economic levels: nano (an individual is an innovator or a consumer), micro (a company), meso (a region), macro (a state), hyper (a global region) and global (Global System) [3]. However, in our work, according to the objectives, we will determine possible lending options and factors of influence at three economic levels (Table 1).

Thus, the forms and methods of lending to innovation activities depend on the following: firstly, on the position of the entity in the system of different levels of the economy; secondly, on the factors of influence, the development of instruments of influence at each level of management of the system of financing innovative programs and projects; thirdly, on the specific purposes of attracting financial resources (current or investment); fourthly, on the terms: short-term, medium-term or long-term; fifthly, depending on the level at which the innovation activity is implemented, the lender will change.

Proceeding from the above, there is a need to create a system of a bank innovative lending, the functioning of which requires consideration of all components of the credit process, their relationship with each other, on the one hand, and with 
Forms, methods and factors influencing the lending of innovation activities at different levels of the economy

\begin{tabular}{|c|c|c|}
\hline Economic level & $\begin{array}{l}\text { Possible forms } \\
\text { and methods of lending }\end{array}$ & Factors of influence \\
\hline Macro & $\begin{array}{l}\text { - project financing } \\
\text { - syndicated lending } \\
\text { - state credit }\end{array}$ & $\begin{array}{l}\text { Investment and innovation climate of the state. } \\
\text { State innovation policy, fiscal policy, monetary } \\
\text { policy. } \\
\text { Development of the national innovation system. } \\
\text { Possibility of state regulation and control of } \\
\text { investments. } \\
\text { Macroeconomic indicators of the country's } \\
\text { economic development. } \\
\text { Technological economy. }\end{array}$ \\
\hline Meso & $\begin{array}{l}\text { - project financing } \\
\text { - syndicated lending }\end{array}$ & $\begin{array}{l}\text { Investment and innovation climate of the region. } \\
\text { State support, development of institutes of } \\
\text { innovative development. } \\
\text { Development of scientific and educational and } \\
\text { general economic infrastructure. } \\
\text { Quality of life of the population of the region, } \\
\text { technological economy of the region. }\end{array}$ \\
\hline Micro & $\begin{array}{l}\text { Bank lending: } \\
\text { - in the form of traditional single } \\
\text { loan to a client, crediting an } \\
\text { account or opening a credit line, } \\
\text { overdraft, leasing; } \\
\text { - by terms: short, medium or } \\
\text { long term }\end{array}$ & $\begin{array}{l}\text { Innovative economic entity, market activity, } \\
\text { competitive environment. } \\
\text { Dependence on the investment climate. } \\
\text { Investment and innovation project. Level of } \\
\text { organizational technologies, innovative potential. } \\
\text { Targeted character of financing. } \\
\text { Resource and investment security, market for } \\
\text { innovative products. } \\
\text { High level of control. }\end{array}$ \\
\hline
\end{tabular}

the elements of macro, meso and microeconomic environment, on the other hand.

Analysis of various sources devoted to the issues of bank lending, suggests that there is no concept of "bank innovation lending system" as a coherent economic category. Some scientific works of modern scholars on lending as a system do not reveal its essence, but merely mention the lending system, focusing on credit risk management, creditworthiness assessment and analysis of the borrower's activity, lending agreement parameters, etc. But the integrated methodology of the systematic organization of bank innovative lending is absent both in scientific publications of foreign authors, and in the works of domestic scientists.

In the most general view, the researchers present a system of bank lending as a set of its constituent elements, which include principles and objects of lending, mechanism for credit provision and repayment, control at various stages of the lending process, while the principles of lending form its main element $[4 ; 5]$. In our opinion, the identification of these elements of lending system as the main ones is not entirely justified, since all the elements are interdependent by their definition and are equally crucial for the effective functioning of the lending system. In addition, this composition of the elements does not reveal the concept of a lending system.
The following definition is of greater interest in terms of the completeness of the elements structure: "Lending system is a set of elements that ensure the rational use of loan resources, which covers the principles, objects, methods of lending, planning credit relations, the mechanism for providing and repaying loans, as well as bank control in the process of lending, that is, includes the elements related to the activity providing loan resources by the creditor" [6]. This definition most closely characterizes the lending system. However, as an important element, the entities and the subject of lending are not named. And such main elements as legal aspects of bank lending are not mentioned.

Consequently, the following objective of this article is to create a system of bank innovative lending, using the system theory in determining the relationships among its components.

In Greek language system is a unit, composed of connected parts, that is, in the most general representation system is a set of elements that are related and tied with each other, forming certain integrity, unity [7].

In management, in most cases, a system refers to an object that has a complex internal structure, a large number of components and elements that interact with each other and with the environment, each of which contributes to the characteristics 
of the whole [8;9]. The application of the system approach allows considering the bank innovative lending as an open system, where the input and output parameters are cash flows and the results of using loan capital (Figure 1).

In accordance with the above, it should be noted that the input and output parameters of the financing systems of innovation programs and projects and of bank innovative lending are interconnected, which implies that the latter is an integral part of the overall system of financing the innovation activity of the country and one of the main elements of development of the industry, region or group of enterprises engaged in innovation activity.

Further, we should note that the complex system of bank innovative lending is a subset of subsystems and consists of a scientific, managerial and managed one, each of them has its own multilevel, complex subsystems.

The subsystem of scientific support of innovative bank lending is based on the scientific approaches of innovative marketing, which depends on the quantity and quality of application of managerial decisions by credit management.

Objective competition laws and time saving require increased costs for improving the quality of strategic decisions at the early stages of the life cycle of innovative lending for the sake of for the sake of repeated savings at the next stages.

The need to select a separate subsystem of scientific support is confirmed by the fact that the lending of innovation activities is defined by the essential features of innovation activities, which are determined through the awareness of the role of innovation in the modern world and the increase of the innovative component in the structure of business processes. Observing the growth of the number of high-tech industries in recent decades, one can state that science plays an increasingly important role in the economy, and not only the level of development of the state affects the science, but the degree of science development determines the speed of progress in the country.

However, we note that the results of the current economic analysis of the enterprise - borrower conducted by commercial banks in Ukraine are oriented towards their internal use, while modern innovative banks in developed financial markets are increasing the costs for organizing and developing their own research, which consists of works of scientific analytical, methodological, informational, expert-control and organizational character, monitoring of changes in legislation and regulatory framework for investment and

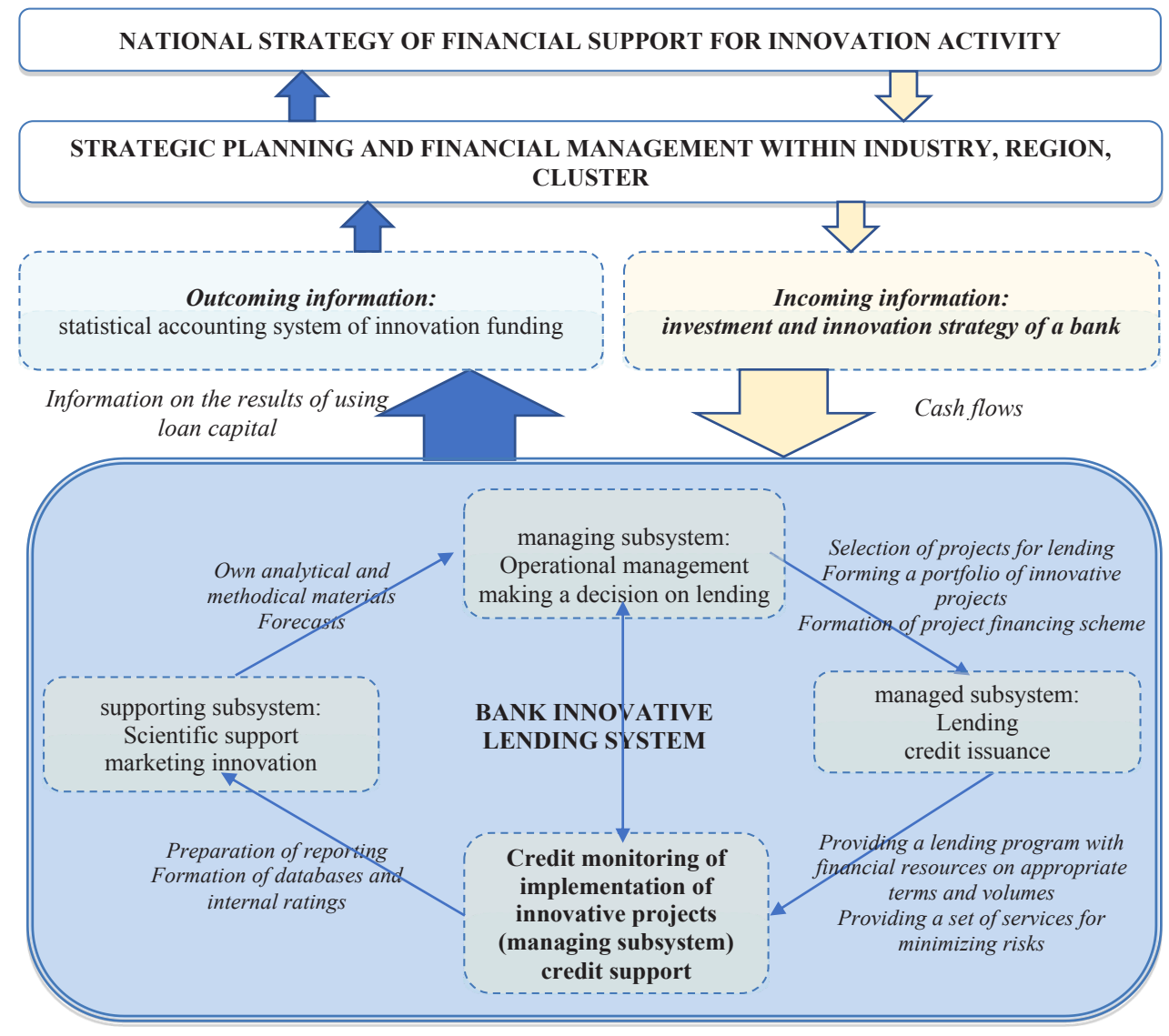

Fig.1. Operating scheme of a bank innovative lending system

Source: compiled by the author 
innovation activities. We believe that these trends are due to several reasons. Firstly, banks provide the clients with their own analytical material in the form of recommendations, market assessments, forecasts, which is an indicator of the high level of service quality and its capabilities. Secondly, quality research and analytical work is the basis of successful investment management, asset management, attracting external financing, and creating conditions for attracting innovation companies as clients [10].

The subsystem that manages is the highest level of the hierarchical structure of the bank innovative lending system. It is represented by systems of operational management of various components of subsystems of the second degree of the hierarchy; for example, the subsystem of the functions of management of the process of innovative lending is an interrelated set of typical processes of planning, organization, coordination and regulation, management of motivation, organization of interaction and control. Each typical process consists of single actions - elements of the system. At the same time all elements, processes, subsystems have different types and numerous connections and interactions.

The managed subsystem. Lending also consists of several stages of the hierarchy. The main task of the first stage of a controlled subsystem is the optimal functioning of its components (personnel, finances). Subsystem of lending is characterized by a complex combination of financial, material, information flows and methods of their processing, which are specified by the effect of technical and technological factors.

The integral elements of the managed subsystem of lending are as follows: entities, object and subject of lending, which collectively determine the form of movement of loan capital.

The entities of innovative bank lending are banks-lenders and loan recipients - legal entities or individuals who are able to perform economic transactions, including credit agreements. These include: commercial enterprises and organizations; nonprofit enterprises and organizations; financial organizations; non-residents - legal entities; entrepreneurs. That is, the entities of bank lending of innovation activity are innovative-active participants of the economy of various organizational and legal forms, various forms of ownership, including entrepreneurs.

The object of lending in the context of our research is the innovative activity of the entity as a specific process. The subject of bank innovative lending is an innovative project initiated by innovation - active enterprises, entrepreneurs and/or banks. The main subject of innovation lending is: modernization of fixed assets (acquisition of high- tech equipment); introduction of new technologies; commercialization of innovative scientific and technical developments; creation of infrastructure (for example, industrial technology parks), etc.

For a bank-lender innovative lending is at increased risk, but in terms of strategic goals of innovation development and national security the availability of such loans (innovative credit) becomes an indispensable tool for banks ' financing innovative development of the economy.

The next component of the subsystem is the methods of lending and means for regulating credit indebtedness, which are defined by the normative documents of central banks, in Ukraine it is the NBU, and represent ways of issuing and repaying a credit in accordance with the principles of lending.

We should note that taking into account the specificity of innovative lending, namely, the need to use long-term financial resources and the inherent nature of a large number of risks, the degree of influence on the subject of lending; banks use direct and indirect lending.

The major direct methods of innovative lending include: the provision of traditional bank loans, opening of credit lines, overdraft and leasing lending, factoring, acquisition of securities of enterprises-innovators by a bank, syndicated lending, project financing, etc.; that is, the direct impact of bank credit as a source of financial support on the development of innovation in the economy.

The main indirect methods of innovative lending include: the participation of bank credits in mezzanine lending, syndicated loans, banking consortia (syndicates) and participation in venture lending; that is, on the basis of these methods the indirect impact of a bank credit on financing innovative development of the economy is carried out.

An important component of the managed subsystem of innovative bank lending is credit risk management, which is carried out in accordance with the credit policy developed individually by each bank according to the requirements of central banks (in Ukraine - the NBU) acting as the regulatory, supervisory and control body of banking activities. This subsystem is also complicated since it is divided into the following components:

- management of the individual borrower's risk, which is carried out by determining the borrower's creditworthiness when making a decision on the provision of an innovative loan; regarding the specifics of the object of lending, great attention is paid to the analysis of cash flows;

- risk management of a bank's credit portfolio, which in the most general form is understood as a set of loans reflecting their dynamics, classified on the basis of criteria of credit risk, profitability and liquidity; 
- management of the provision of loan repayment; bank managers determine the most effective for each innovative loan forms and types of security; the valuation of collateral may be based on the expert judgment of an independent appraiser, in accordance with the recommendations of the central bank, or on the basis of the internal bank methodology.

We should note that the management system for promoting active participation of bank credit as a source of funding for innovative development of economy of Ukraine is advisable to form considering the tasks at three levels, mentioned by us earlier, namely, at macro-, meso- and microeconomic levels.

At the macroeconomic level, the participation of bank innovative loans is determined by the formation and implementation of a national strategy of financial support for innovation activities (including implementation of large innovative projects, promoting the activity of innovative and active small and medium enterprises, development of export-oriented innovative business).

At the mesoeconomic level commercial banks serve as regional leaders of the state innovation policy, assessing the innovative potential of the region, forming the demand of companies for financial resources, lending by redistributing financial resources in favor of priority projects.

The microeconomic level is represented by commercial banks, which form the corresponding business processes for the realization of the tasks of innovative lending of previous levels and independently build up a policy in support of innovative projects of their clients on the basis of available financial resources.

We also consider it necessary to note that modern bank innovative lending in Ukraine is in a difficult situation due to a number of circumstances, the main of which are the following:

- enterprises engaged in innovative activities usually are not able to provide the necessary collateral, and intangible assets which is available in the company are not accepted by banks as collateral;

- limited ability of banks to take high risks because the NBU, in accordance with the recommendations of the Basel Agreements, establishes more rigid standards of liquidity and capital adequacy, provisioning methodology for credit operations for commercial banks, which significantly complicates the development of innovative lending;

- lack of methods for assessing the solvency of borrowers who carry out innovation activities, which complicates the assessment of risks of the innovation project and prevents the possibility of setting the rate for innovative credits at the level that applies to ordinary borrowers;
- problems in the banking system, the complex macroeconomic environment cause the limited long-term credit resources needed for lending innovative projects both on the external and on the local market, which also increases its cost.

The solution of the above-mentioned problems requires the state promotion for lending innovation activities, which is one of the elements of the state innovation policy of the country and is intended to intensify the activity of commercial banks of Ukraine. The measures aimed at improving profitability and innovative credit operations of banks, may include:

1) exemption from taxation of bank profits received from operations with innovative lending;

2) reduction of the current tax rate in relation to the bank profits received as a result of innovative lending operations;

3) reduction of the rate of obligatory reserve of resources attracted for a term of one year, which, on the one hand, will lead to an increase in the resource base of innovative lending, and on the other hand, will reduce the value of these loans for the final borrower;

4) granting banks the right to include the value of the mortgaged property (property rights) of the borrower in the calculation of the amount of the provision for compensation for possible losses on the provided innovative loans in the amount of not less than $50 \%$ of the market value of collateral;

5) exemption from taxation of bank profits obtained as a result of lending to innovative projects of strategic importance to the state.

In turn, in order to reduce the risk of banks' lending and innovation activities, it is necessary: to further strengthen the stability of the national currency; to implement the mechanism of long-term refinancing commercial banks by the National Bank of Ukraine based on the availability of highly effective innovative projects that have a strategic priority in terms of the objectives of state economic policy; to introduce the mechanism of state subsidies for interest rates on innovative loans; to organize state insurance of innovative loans and provide state guarantees on strategically priority directions of innovative financing; to create mechanisms for financing innovative projects within the framework of public-private partnership as it contributes to harmonization of interests of the state and business in the innovative development and increase of investment resources.

Only creating conditions for attracting financial resources for innovation and ensuring the development of a system of preferential bank lending for innovations can lead our country to a new, innovative stage of development. 
Conclusions from the conducted research.

1. It has been studied that creating a bank innovative lending system needs to take into account all the components of the lending process, their relationship with each other and with elements of macro-, meso- and microenvironment that determine the optimal conditions of its operation.

2. It is determined that the system of bank innovative lending is intended to ensure the rational use of loan resources and represents a set of multi-level subsystems, which are as follows:

- scientific support (organization and development of own research: scientific, analytical, methodical, information, expert-control and organizational works, monitoring of changes in legislation and the regulatory framework of investment and innovation);

- operational management (management functions of innovative lending: planning, organization, coordination, regulation, motivation management, organization of interaction and control);
- lending (form of movement of loan capital, lending practices, methods of regulation of credit debt, credit risk management, subject to regulation, supervision and control by the NBU).

3. It is determined that at the current stage of development the bank innovative lending in Ukraine is in a difficult situation, its promotion will be facilitated only by state incentives aimed at providing a higher level of profitability of credit-innovative operations and reducing the level of bank risks from investing to innovative projects in comparison with risks from investing other active banking operations.

4. It is recommended, as a further development, to ensure the promotion for bank innovative lending in Ukraine at the expense of creating conditions by the state for reducing bank risks while lending investment projects by guaranteeing credit financing of innovations on a competitive basis with the priority of implementing multi-sectoral and multi-purpose projects.

\section{References:}

1. Poliak, N.P. (2014). Bankivs'ke kredytuvannia: suchasnyj stan ta problemy s'ohodennia [Bank lending: the current state and problems of the present days] Visnyk Chernihivs'koho derzhavnoho tekhnolohichnoho universytetu. Seriia "Ekonomichni nauky": naukovyj zbirnyk Bulletin of the Chernihiv State Technological University. Series "Economic Sciences": scientific collection, 2 (74), 201-207 [in Ukrainian].

2. Folom'eva, A.N. (2007). Innovacionnyj tip razvitija jekonomiki [Innovative type of the economy development]. Moskva: RAGS [in Russian].

3. Dovbij, I.P. (2010). Kreditovanie innovacionnoj dejatel'nosti $v$ sisteme gosudarstvenno-chastnogo partnerstva [Lending the innovation activity in the system of a public-private partnership]. Moskva: VZFJel [in Russian].

4. Lavrushin, O.I. (2001). Bankovskoe delo [Banking]. Moskva: Finansy i statistika [in Russian].

5. Filimonova, O.B. (n.d.). Systema ta mekhanizm bankivs'koho kredytuvannia pidpryiemstv: zv'iazok i protystavlennia sutnosti poniat' [System and mechanism of the bank lending to enterprises: correspondence and opposition of the concepts nature]. Retrieved from http://lib.chdu.edu.ua/pdf/ naukpraci/economy/2016/275-263-10.pdf [in Ukrainian].

6. Beloglazova, G.N. Kroliveckij, L.P. (2008). Bankovskoe delo [Banking]. Moskva: Finansy i statistika [in Russian].

7. Soroka, K.O. (2004). Osnovy teorii system i systemnoho analizu [Foundation of Systems Theory and System Analysis]. KhNAMH [in Ukrainian].

8. Zavads'ka, D.V. (2018). Kontseptualizatsiia pidkhodu do formuvannia systemy innovatsijnoho seredovyscha rozvytku ekonomiky [Conceptualization of the approach to the formation of the innovative environment system for the economy development] Mizhnarodnyj naukovo-vyrobnychyj zhurnal "Stalyj rozvytok ekonomiky" - International Scientific and Industrial Journal "Sustainable Development of the Economy", 2, 138-149 [in Ukrainian].

9. Illiashenko, S.M. (2010). Innovatsijnyj menedzhment [Innovative management]. Sumy: VTD Universytets'ka knyha [in Ukrainian].

10. Ustinovich, V. (2011). Monitoring bankom investicionnogo proekta [Bank Monitoring of the investment project]. Bankay̆ski vesnik. - The Bank Bulletin, 5, 58-62 [in Russian]. 